Iryna Pavlenko

Uniwersytet Warszawski

\title{
Актуализация конфликта Нагорного Карабаха: анализ с разных сторон и точек зрения
}

1 агорно-Карабахский конфликт - это конфликт двух цивилизаций: региональных конфликтов на постсоветском пространстве. Нынешний этап конфликта берет свое начало еще с 80-х годов прошлого столетия во время существования СССР и перерос в противостояние двух независимых государств: Азербайджанской Республики и Республики Армения.

Карабах - живописная территория в Закавказье, древнейшие земли, имеющие великую историческую ценность и значение не только в азербайджанской и армянской истории, а и для мира в целом. Именно на территории горной части Карабаха, в Ходжавендском районе Азербайджана в пещере Азых были обнаружены следы, орудия людских поселений, а также останки древнего человека (азыхантроп), что причисляет данную местность к регионам формирования современного человечества на ряду со Средиземноморьем и Восточной Африкой [Пещера была обнаружена советским азербайджанским учёным М.Гусейновым в 1960 г.].

Основной целью данной публикации является анализ средств массовой информации, представляющих данный конфликт с разных сторон, разных стран, с разных точек зрения. Кому же из двух народов исторически принадлежит данная территория? Каждая из стран твердо отстаивает свою позицию. Так из статьи о Нагорно-Карабахском конфликте на официальном сайте министерства иностранных дел Республики Армения можно почерпнуть, что «Арцах» (Карабах) является неотъемлемой частью исторической Армении. В эпоху Урарту (IX-VI вв. до н.э.) Арцах был известен под именем Уртехе-Уртехини. Об Арцахе, как части Армении, есть упоминания в работах Страбона, Плиния Старшего, Клавдия Птолемея, Плутарха, Диона Кассия и других античных авторов. Ярким свидетельством этого является также 
и сохранившееся богатое культурно-историческое наследие ${ }^{492}$. В то время как азербайджанские источники же гласят о том, что в данный исторический период на юге Азербайджана находилось могущественное государство Манна (IX-VI вв. до н.э.). В то время не только в Карабахе, но и на Южном Кавказе (Закавказье) вообще не было армянского этноса ${ }^{493}$.

По некоторым данным первое появление армян на территории Закавказья датируется II в. до н.э. и повлекло начало агрессивных действий против местных государств и народов. В этот период армяне развивали Армянскую империю на востоке Малой Азии так называемую «Великой Арменией» и пытались охватить все заселенные ими территории. После смерти царя империи Тиграна II вымышленная легенда о «Великой Армении» сошла на нет, и они стали вассалами Рима и были ими до IV века. Однако, в отличие от армян, азербайджано-албанское государство продолжало проводить независимую политику, и исторические районы Карабаха были ее частью ${ }^{494}$.

В разные времена территория Карабаха подпадала под оккупацию арабского халифата, принадлежала албанскому государству, входила в состав Верховного монгольского каганата, а затем государства Хулагу (Эльханидов), входила в состав азербайджанских государств Гарагоюнлу и Аггоюнлу, подпадал под владения пяти албанских феодальных княжеств, была одним из княжеств государства Сефевидов и отдельным Карабахским ханством.

С 1783 года российское государство начало вмешиваться в борьбу за оккупацию Южного Кавказа, пытаясь создать «христианское государство» на территории Азербайджана, а точнее - поддержать себя. В конце 18-начале 19 веков агрессия России усилилась, Карабахское ханство было присоединено к России как мусульманскоазербайджанская земля ${ }^{495}$.

\footnotetext{
492 Нагорно-Карабахская проблема. [Электронный ресурс]: Министерство Иностранных Дел Республики Армения. URL: https://www.mfa.am/ru/nagorno-karabakh-issue

${ }^{493}$ История Нагорного Карабаха. [Электронный ресурс]: Национальная Академия Наук Азербайджана. Институт Молекулярной Биологии и Биотехнологий. URL: https:/imbb.az/az/news/841

${ }^{494}$ Карабах с древнейших времен до времен ханств. [Электронный ресурс]: Виртуальный Карабах. Центр информационно-коммуникационных технологий. URL: https:/www.virtualkarabakh.az/az/postitem/22/32/qarabag-en-qedim-zamanlardan-xanliqlar-dovrunedek.html

495 Организация Объединенных Наций. Международные Договоры по Правам Человека. Основной документ, являющийся составной частью докладов государств-участников. Азербайджанская Республика [31 января 2002 года]. [Электронный http://docstore.ohchr.org/SelfServices/FilesHandler.ashx?enc=FhOD6sgqgzAhFXD9F\%2FeKaFMm83LbFY75 RhkIFGrig\%2B4vCnJiMzyLfHoDODRgFZF3aJ3o6haDraXwhCUv4X9ErNAKk1jrzXC0JwCMI76aA8tjpCjgK TwcOZaTjfCAhJDarYCBalKNgtnsv4rBkqeixA\%3D\%3D
} 
Когда Российская империя распалась, в Карабахе вспыхнули кровопролитные армяно-азербайджанские столкновения. Противостояние шло вплоть до момента, когда в Азербайджане установилась советская власть. Рабоче-крестьянская Красная Армия подавила армянские восстания в Карабахе. Решением властей территория была признана частью Азербайджанской ССР, что вызвало недовольство армянской стороны $^{496}$.

В советское время руководство Армении неоднократно поднимало вопрос об отделении Нагорного Карабаха от Азербайджана и находило сторонников решить этот вопрос в свою пользу. Однако каждый раз после вмешательства руководства Азербайджана незаконные предложения руководства Армении отклонялись.

Современный этап Нагорно-Карабахской проблемы начался в 1988 году. Столкновения между армянскими и азербайджанскими общинами, выселение азербайджанцев с территорий Нагорного Карабаха и Армении, ответные погромы в азербайджанском городе Сумгаит - всё это переросло в первую Карабахскую войну, а спустя время и во второй крупномасштабный, 44-дневный вооруженный конфликт между странами, когда Армения и Азербайджан обвинили друг друга в усугублении конфликта и нарушении режима прекращения огня.

Конфликт в Карабахе не раз обсуждался в ОНН и стал основанием принятия Советом Безопасности четырех резолюций, ни одна из которых не была исполнена ${ }^{497}$. По данным сайта Генеральной Прокуратуры Азербайджанской Республики резолюции не дали результата из-за деструктивной позиции Армении ${ }^{498}$. На разных уровнях принимались попытки посадить стороны за стол переговоров, но при смене власти переговорный процесс приходилось начинать сначала. Вопросом Карабахского конфликта занимается Минская группа ОБСЕ при сопредседательстве России, США и Франции.

Существуют различные точки зрения на участие России в урегулировании Нагорно-Карабахского конфликта. По мнению украинского журналиста Дмитрия Гордона, в разгаре современного конфликта причастна в первую очередь Россия,

\footnotetext{
496 Нагорный Карабах: история земли, за которую снова разгорается война. [Электронный ресурс]: Информационное агентство «В городе N». URL: https://www.vgoroden.ru/statyi/nagornyy-karabah-istoriyazemli-za-kotoruyu-snova-razgoraetsya-voyna

497 Что случилось в Нагорном Карабахе? Отвечаем на главные вопросы. [Электронный ресурс]: ВВС News. Русская служба. URL: https://www.bbc.com/russian/features-54427054

49844 gün sürən Vətən Müharibəsi (II Qarabağ müharibəsi). [Электронный ресурс]: сайта Генеральной Прокуратуры Азербайджанской Республики. URL: https://genprosecutor.gov.az/az/page/azerbaycan/i-ve-iiqarabag-muharibesi/44-gun-suren-veten-muharibesi-ii-qarabag-muharibesi
} 
которая всегда действовала по принципу «разделяй и властвуй». Журналист считает, что конфликт был подогрет Россией, как и советскими спецслужбами в 1989 году, что спровоцировало ожесточенное противостояние между двумя древними мудрыми народами ${ }^{499}$.

Нагорно-Карабахский конфликт повлек за собой множество потерь и разрушений как людских жизней так зданий и даже городов. Так по данным министерства внутренних дел Азербайджанской Республики на территории Азербайджана повреждены или разрушены порядка 900 населенных пунктов, 150000 домов, 7000 общественных сооружений среди которых школы, детские сады, библиотеки и многое другое. Число погибших достигает 20000 человек и 50000 раненных. В ходе конфликта более 6000 граждан Азербайджана пропали без вести и были захвачены в плен ${ }^{500}$. В результате оккупации земель Нагорного Карабаха многие семьи азербайджанского происхождения стали беженцами и вынужденными переселенцами с родных поселений. По данным Государственный комитет по делам беженцев и вынужденных переселенцев Азербайджанской Республики количество составило более миллиона человек. Эта проблема обсуждалась еще в 2014 году на встрече заместителя премьер-министра Азербайджанской Республики и председателя выше упомянутого комитета с британским министром по делам Европы Дэвидом Лидингтоном. Дэвид Лидингтон выразил сожаление по поводу того, что армяноазербайджанский Нагорно-Карабахский конфликт долгое время не решается, и сказал, что мировое сообщество должно уделять больше внимания урегулированию этого конфликта ${ }^{501}$. Министр так же отметил, что сохранения статуса-кво не выгодно как конфликтующим сторонам, так и мировому сообществу.

В ходе длительного противостояния политические силы Азербайджана так же потеряли надежду на разрешение конфликта путем вмешательства со стороны международных организаций. Так на последнем VIII Бакинском глобальном форуме, который состоялся 4-6 ноября 2021 года министр иностранных дел Азербайджана

\footnotetext{
499 Путин не стал воевать в Карабахе - Гордон назвал две причины. [Электронный ресурс]: Телеканал Украина 24. URL: https://old.u24.ua/vmire-news/5734-putin-ne-stal-voevat-v-karabahe-gordon-nazval-dveprichiny

500 Последствия военной агрессии Армении против Азербайджанской Республики [Электронный ресурс]: Министр внутренних дел Азербайджанской Республики. URL: https://mia.gov.az/?/ru/content/29863

${ }^{501}$ British Minister was informed about the realities about Nagorno-Karabakh conflict [Электронный ресурс]: Site of State Committee For Affairs Of Refugees and Internally Displaced Persons Of The Republic Of Azerbaijan. URL: http://idp.gov.az/en/news/342
} 
Джейхун Байрамов заявил, что доверие к ОНН было подорвано из-за не результативности переговоров и резолюций организации ${ }^{502}$. Так же министр говорил о том, что власти страны призывают мировое сообщество к созданию нового мирового порядка. Ведь Азербайджанская Республика и многие другие страны заинтересованы в повышении эффективности $\mathrm{OOH}$ в решении конфликтных ситуаций между государствами и нациями.

Азербайджанская воля к победе и уверенность в собственной исторической правоте настолько безгранична и пропагандируется со всех источников. Так, например, на сайте Верховного суда Азербайджанской республики отдельно вынесен баннер “кричащий” посетителям о том, что Карабах - это Азербайджан. А также цитируется общенациональный лидер Азербайджана Гейдар Алиев: “Я верю, что Ильхам Алиев сможет завершить те судьбоносные вопросы, планы и работы, которые мне не удалось выполнить. Я верю в него так же сильно, как и в себя, и у меня большие надежды на его будущее" ${ }^{\circ 03}$. Уверенность политических сил Азербайджана в том, что НагорноКарабахский конфликт должен быть решен в пользу Азербайджанской республики так же, транслируется и сайта комиссара по правам человека Азербайджанской Республики. В одной из статей так же можно найти упоминание о том, что после решения конфликта в пользу страны, Азербайджан должен стать общим домом для всех проживающих в ней народов ${ }^{504}$.

В своем обращении к народу Президент Азербайджанской Республики Ильхама Алиева от 10 ноября 2020 года поздравил население страны с одержанной победой в сорока четырехдневной войне и конфликте, который более 30 лет сохранялся между народами двух стран. Алиев называет подписанное заявление историческим, как для истории страны, так и в целом, так как было подписано в формате видеоконференции. Президент достаточно резко и однозначно выразился в отношении премьер-министра Армении Пашиняна, который в последний момент отказался публично подписывать заявление. Так же главнокомандующий страны высоко оценил усилия как президента

\footnotetext{
${ }^{502}$ Foreign Minister said UN's activity produced no effect in Karabakh resolution [Электронный ресурс]: Report News Agency URL: https://report.az/en/karabakh/foreign-minister-said-un-s-activity-produced-no-effectin-karabakh-resolution/

${ }^{503}$ Karabakh is Azerbaijan! [Электронный ресурc]: The Supreme Court of Azerbaijan Republic URL: http://www.supremecourt.gov.az/en/static/view/295

${ }^{504}$ Karabakh [Электронный pecypc]: Ombudsman The Commissioner for Human Rights of the Republic of Azerbaijan URL: https://ombudsman.az/en/view/pages/133
} 
Турции Реджепа Тайипа Эрдогана, так и президента России Владимира Путина, которые приложили большие усилия, чтобы решить вопрос мирным путем.

Поддержка Азербайджана Турцией в противостоянии 2020 года имела влияние на исход военных действий. Дружественное отношение народов Турции и Азербайджана опираются на прочные основы, такие как общая история и национально-нравственные ценности народов. Находящийся с визитом в Азербайджане Мехтеранский союз Министерства национальной обороны Турецкой Республики выступил на концерте по случаю Дня Победы в Центре Гейдара Алиева. В своей речи министр обороны Турции Хулуси Акар заявил, что Карабах сегодня свободен и присоединился к своей родине и что азербайджанские турки не пали перед трудностями. ${ }^{505}$

На встрече премьер-министра Азербайджанской Республики Али Асадова с делегацией во главе с председателем Великого национального собрания Турции Мустафой Сентопом подкомитет Комитета по правам человека Великого Национального Собрания Турции изучает случаи нарушения прав человека в зонах боевых действий, включая Нагорный Карабах, и готовится опубликовать отчет о преступлениях против человечности, совершенных Арменией против мирного население Азербайджана ${ }^{506}$.

В своем интервью о взаимоотношениях России и Турции министр обороны России Сергей Шойгу так же упомянул о российско-турецком сотрудничестве в вопросе урегулирования ситуации в Нагорном Карабахе. Он называет операцию очень сложной, потому как в ней было задействовано огромное количество аргументов, элементов, мотивов, в результате чего люди перестали убивать друг друга ${ }^{507}$.

В сентябре 2021 года на заседании правительства Армении Пашинян в своей речи, говоря об открытии коммуникаций в регионе Карабаха, признал, что это западные территории Азербайджанской Республики, чем несомненно порадовал жителей Азербайджана и местные СМИ, которые разнесли новость по своим

505 Karabakh is free today - Turkish Defense Minister says [Электронный pecypc]: APA. URL: https://apa.az/en/herbi_xeber/karabakh-is-free-today-turkish-defense-minister-says-361456

506 Prime Minister Ali Asadov received the Vice President of the World Bank [Электронный ресурс]: Republic Of Azerbaijan Cabinet Of Ministers URL: https://nk.gov.az/en/article/1144/

${ }^{507}$ Sergei Shoigu: Nagorno-Karabakh is very difficult operation [Электронный pecypc]: Newtimes.az Analytical Information Portal. URL: http://newtimes.az/en/interview/7310/ 
источникам ${ }^{508}$. Однако заявление подобного характера так же вызвало бурю негодование среди армян, которые никоим образом не хотят мириться с новой реальностью.

После подписания трехстороннего заявления о прекращении огня и заключение мирных договоренностей на территории, соединяющей Армению и Азербайджан, был развернут шестикилометровый горный коридор, где располагается миротворческий контингент Российской Федерации во избежание повторных конфликтов между странами. Однако в некоторых источниках так же сообщается о деструктивной деятельности армян на территории коридора. Так, например, 13 ноября 2021 года армянский террорист бросил ручную гранату в военнослужащих азербайджанской армии и российского миротворческого контингента на блокпосте в Карабахе. По словам эксперта Ильгара Вализаде после незаконного визита министра обороны Армении Аршака Карапетяна в Карабах подобные провокации осуществляются систематически ${ }^{509}$. Что не способствует стабильности в регионе, напротив, они могут привести к напряженности в отношениях между азербайджанскими военнослужащими и российскими миротворцами.

Некоторые источники так же говорят о напряженности между Азербайджаном и российским миротворческим контингентом. Основой раздора служит неспособность последних предотвратить переброску армянских вооруженных сил в Карабахский регион, который частично находится под временным контролем российских миротворцев ${ }^{510}$. Посему страны по очереди проводят учения на территории Лачинского коридора. Учения российских миротворцев должны были сигнализировать армянскому обществу о готовности Москвы обеспечить защиту коридора. В свою очередь следующими стали учения азербайджанских и турецких войск в районе Лачинского коридора. Основная цель совместных учений по данным сайта Министерства Обороны Азербайджанской Республики - повышение оперативной совместимости подразделений спецназа дружественных стран и стран-партнеров в ходе боевых действий, подготовка

\footnotetext{
508 Armenian PM admits that Karabakh is territory of Azerbaijan [Электронный pecypc]: Trend News Agency. URL: https://en.trend.az/azerbaijan/politics/3481189.html

${ }^{509}$ Expert: Provocations intensified after Armenian defense minister's illegal trip to Karabakh [Электронный pecypc]: AZӘRBAYCAN 24 URL: https://www.azerbaycan24.com/en/expert-provocations-intensified-afterarmenian-defense-minister-s-illegal-trip-to-karabakh/

${ }^{510}$ Azerbaijan Increasingly Critical of Russia's Peacekeeping Mission in Karabakh [Электронный pecypc]: The Jamestown Foundation. Eurasia Daily Monitor Volume: 18 URL: https://jamestown.org/program/azerbaijanincreasingly-critical-of-russias-peacekeeping-mission-in-karabakh/
} 
к действиям в мирное и военное время, обмен знаниями и опытом ${ }^{511}$. Азербайджанские СМИ представили азербайджано-турецкие учения как «особое предупреждение» против любых провокаций в Карабахском регионе.

Так же в ходе современной истории Нагорно-Карабахского конфликта нельзя не отметить факт поддержки ЕС армянской стороны. Так на встрече министра иностранных дел Армении Арарат Мирзоян и спецпредставитель ЕС на Южном Кавказе Тойво Клаар последний подтвердил политическое обязательство ЕС продолжать оказывать поддержку Армении в приоритетных областях ${ }^{512}$. Такая поддержка связана с тем, что на территории Азербайджана по-прежнему находятся военнопленные армянского происхождения.

После возвращения в состав Азербайджанской Республики земель, долго находящихся под оккупацией, восстановление освобожденных территорий имеет большое значение как с точки зрения развития Карабахского региона, так и развития экономики Азербайджанаи прописано в документе «Азербайджан 2030: национальные приоритеты социально-экономического развития», утвержденном Указом Президента Ильхама Алиева 2 февраля 2021 года. Так в Физулинском районе был заложен фундамент нового аэропорта, ведутся работы по реконструкции и реставрации разращенных сооружений, строится жилищная инфраструктура. «На освобожденных от оккупации территориях ведутся восстановительные работы, вновь слышны звуки азана в наших мечетях», - отметил министр финансов Азербайджана Самир Шарифов на пленарном заседании парламента ${ }^{513}$.

Со слов президента Алиева достижения поставленных целей принимаются комплексные меры, успешно реализуются многоцелевые логистические проекты, проекты «умный город», «умная деревня» с использованием современных технологии,

511 The "Three Brothers - 2021" International Exercises of the Special Forces will be held in Baku [Электронный ресурc]: Ministry Of Defense Of Azerbaijan URL: https://mod.gov.az/en/news/the-threebrothers-2021-international-exercises-of-the-special-forces-will-be-held-in-baku-37586.html

512 Toyko Klaar discussed the situation around Karabakh with the Foreign Minister and the Prime Minister of Armenia [Электронный pecypc]: Turan News Agency URL: https://www.turan.az/ext/news/2021/9/free/politics_news/en/7667.htm/001

513 Самир Шарифов: Ведутся работы по ускорению возвращения в Карабах и Восточный Зангезур [Электронный ресурс]: Новостной портал Media.az URL: https://media.az/politics/1067837283/samirsharifov-vedutsya-raboty-po-uskoreniyu-vozvrascheniya-v-karabah-i-vostochnyy-zangezur/ 
предпринимаются важные шаги по превращению Карабаха в источник альтернативной энергии, зону «зеленой энергии» ${ }^{514}$.

По словам главы России Владимира Путина, урегулирование подобных конфликтов представляет особую ценность, имеют особое значение, играют особую роль для государства. Россию связывают с этими республиками многовековые связи. Это имеет внутриполитическое измерение в этой связи, и представляет очень большой интерес с точки зрения внутренней безопасности, с точки зрения политики. Направление СНГ для России является приоритетным по внешней политике и с экономической точки зрения ${ }^{515}$.

По мнению азербайджанского аналитика Мурада Мурадова, Россия прекрасно понимает, что стратегический и экономический ущерб от испорченных отношений с Азербайджаном, неизбежный в случае ее прямой поддержки Армении, не может быть компенсирован самым тесным союзом с Ереваном. Еще один ключевой фактор, определяющий подход России, - сложные и противоречивые отношения Москвы с Турцией ${ }^{516}$.

Бывший сопредседатель Минской группы ОБСЕ от США Джеймс Уорлик считает, что Россия активно работает за кулисами, чтобы предотвратить более широкий конфликт. По его словам, сопредседатели Минской группы США, Франция и ОБСЕ должны более активно сотрудничать в этом вопросе ${ }^{517}$.

Вашингтон является одним из сопредседателей Минской группы посредников и потому официально не поддерживает ни ту ни другую сторону. В свою очередь 45 президент Соединенных Штатов Америки Дональд Трамп во время выступления на предвыборном митинге в штате Нью-Гемпшир назвал проблему Карабахского противостояния легкой, а армян - невероятными людьми, которые дерутся как черти. Ранее Трамп высказывался об армяно-азербайджанском конфликте скупо ${ }^{518}$.

\footnotetext{
${ }^{514}$ Karabakh will become a modern and the most developed part of the region [Электронный pecypc]: Official information resources of the Ministry of Emergency Situations of the Republic of Azerbaijan URL: https://www.fhn.gov.az/newspaper/?en/news/view/9585

515 Совещание о российской миротворческой миссии в Нагорном Карабахе[Электронный ресурс]: Официальный сайт Президента России. URL: http://kremlin.ru/events/president/news/64455

516 Мурад Мурадов: Россия и Вторая Карабахская Война. [Электронный ресурс]: Центр Досліджень Армії, Конверсії Та Роззброєння. URL: https://cacds.org.uа/мурад-мурадов-россия-и-вторая-карабах/

${ }^{517}$ Qarabağda sülhlə bağlı 7 sual. Bundan qazanan kimdir və sonra nə olacaq? [Электронный pecypc]: BBC News. Azerbaycanca. URL: https://www.bbc.com/azeri/region-54878142

518 Трамп: "Армяне дерутся как черти". [Электронный ресурс]: BBC News. URL: https://www.bbc.com/russian/live/news-54317944
} 
Президент Белоруссии Александр Лукашенко еще в 2016 году предлагал тогдашнему лидеру Армении отдать часть непризнанной Нагорно-Карабахской республики Азербайджану за крупную сумму. В современных же реалиях Лукашенко белорусский лидер выразил одобрение ранее принятой договоренности о прекращении военных действий, достигнутой в результате обострения вооруженного противостояния в зоне Нагорного Карабаха осенью 2020 года ${ }^{519}$.

По мнению политолога-востоковеда Алексея Малашенко Армения и Азербайджан будут настаивать каждый на своей победе и одновременно опасаться проигрыша в глазах и своих, и мирового сообщества. Однако ни Армении, ни Азербайджану продолжение военной схватки на самом деле не выгодно. По его словам, победы в конфликте никто не добьется, а участие Турции на стороне Азербайджана лишь амбиции Эрдогана заявить о лидерстве и в мусульманском мире, в тюркском сообществе под своим патронажем, претендует на особую роль на Ближнем Востоке 5 .

Журналист немецкого издания Deutsche Welle в одной из статей пишет мнение о нехватке искреннего посредника в конфликте вокруг Нагорного Карабаха, так как Россия и Турция имеют свои цели. А также, что конфликт постоянно разгорается с целью отвлечь внимание от ухудшения экономической ситуации стран-соперников. Так, например, не реализованы обещания президента Азербайджана о модернизации экономики и преодолении коррупции ${ }^{521}$.

Армяно-американский академик основатель Центра региональных исследований в Ереване Ричард Гирагосян, критически оценил роль ЕС в карабахском конфликте и назвал оглушительной тишину со стороны мирового. Но также отметил, что для Армении это не повод отвернуться от демократии и европейской модели развития так как «российские ценности коррупции и авторитаризма имеют больше общего с Азербайджаном, а не с Арменией» ${ }^{522}$.

Федеральный министр обороны Аннегрет Крамп-Карренбауэр назвала в своем докладе в Университете Гельмута Шмидта в Гамбурге современную войну в Нагорном

\footnotetext{
519 Лукашенко поздравил Армению и Азербайджан с окончанием конфликта в Карабахе. [Электронный pecypc]: ИА Красная Весна. URL: https://rossaprimavera.ru/news/f7197bf7

520 Политолог Алексей Малашенко - об иранском факторе в Нагорном Карабахе. [Электронный ресурс]: Журнал "Огонёк" №41 от 19.10.2020, стр. 16 URL: https://www.kommersant.ru/doc/4529330

${ }^{521}$ Коментар: Кому вигідна війна за Нагірний Карабах [Электронный ресурc]: Deutsche Welle. URL: https://p.dw.com/p/3jAnG

522 Эксперты о ситуации в Карабахе: мир с далеко идущими последствиями [Электронный ресурс]: Deutsche Welle. URL:https://p.dw.com/p/3lcS7
} 
Карабахе первой в истории человечества настоящей войной беспилотников между двумя странами ${ }^{523}$.

По словам Эрика Чана, специалиста по китайско-корейской политике и вопросам безопасности, из-за сочетания современных и старых систем с инновационными методами Азербайджан разрушил сильные укрепления Армении, тем самым получил преимущество во второй Нагорного Карабахской войне $\mathrm{e}^{524}$.

В заявлении Европейского Парламента от 30 июля 2021 года можно найти критику в отношении азербайджанской стороны конфликта, которая в своем заявление высказались относительно так называемого «Западного Зангезура» и назвали часть территории Республика Армения азербайджанской «исконной землей». Такие заявления в высшей степени безответственны и угрожают дальнейшим подрывом региональной безопасности ${ }^{525}$.

Президент Франции Эммануэль Макрон призвал Азербайджан вывести свои войска с «суверенной территории Армении» после серии недавних пограничных инцидентов между двумя странами Южного Кавказа, которые усилили региональную напряженность, также призвал двух соседей установить свои границы путем переговоров ${ }^{526}$. Так же Макрон выразил поддержку Франции народа Армении заявлением на своей странице в социальной сети Twitter.

Подобные заявления и недовольство народа Армении повлекли за собой инициацию первого разбирательства в Международном суде ООН, главном судебном органе Организации Объединенных Наций, уполномоченном разрешать правовые споры между государствами. Армения заявляет о нарушениях Азербайджаном Международной конвенции о ликвидации всех форм расовой дискриминации, в том числе о нарушениях, совершенных во время прошлогодней жестокой войны из-за

\footnotetext{
${ }^{523}$ Second Keynote Speech by German Federal Minister of Defence [Электронный pecypc]: Federal Ministry of Defence. URL:https://www.bmvg.de/en/news/second-keynote-speech-german-minister-of-defence-akk-4503976 ${ }^{524}$ Chan, Eric, "What Taiwan's Military Can Learn From the Armenia-Azerbaijan War". December 09, 2020. [Электронный ресурc]: The Diplomat. URL: https:/thediplomat.com/2020/12/what-taiwans-military-can-learnfrom-the-armenia-azerbaijan-war/

525 European Parliament URL: https://www.europarl.europa.eu/cmsdata/238542/20210730_AZAM\%20border\%20clashes_joint\%20statement.pdf

${ }^{526}$ France's Macron Calls For Azerbaijani Troop Pullout From 'Armenian Territory' [Электронный ресурс]: Radio Free Europe/Radio Liberty. URL: https://www.rferl.org/a/france-macron-nagornokarabakh/31284862.html
} 
Нагорного Карабаха. В ответ Азербайджан через неделю подал аналогичное заявление ${ }^{527}$.

Российское интернет издание «Вести», ссылаясь на «РИА Новости», информирует и в то же время предостерегает своих читателей, приводя в качестве примера данные компании Stratfor, касательно опубликованной карты расширения сферы влияния Анкары до 2050г.: «Карту расширения сферы влияния Анкары, подготовленную ранее компанией Stratfor, продемонстрировал турецкий государственный телеканал TRT1. Созданная в 1996 году американская компания, которую иногда называют "теневым ЦРУ", прогнозирует расширение турецкого влияния к 2050 году сразу на целый ряд стран Балкан, Северной Африки, Закавказья, Средней Азии, Ближнего Востока и даже на часть России. В зону влияния Турции должны, по оценкам специалистов Stratfor, попасть Азербайджан и Армения, Грузия, Египет и Сирия, Саудовская Аравия, Ирак, Греция, Кипр, Ливия, Йемен, ОАЭ, а также части азиатских республик бывшего СССР, сообщает РИА Новости» ${ }^{528}$.

Фундамент многовековой истории конфликта между Арменией и Азербайджаном послужил условием интереса со стороны России обеспечить обе стороны противостояний значительным вооружением. С одной стороны, экономическая подоплёка сделок по поставкам оружия содержала производственный интерес ВПК России, с другой и гораздо более весомой стороны, поставки вооружений имели геополитический контекст. Пресловутая фраза «разделяй и властвуй» проверенная практикой тысячелетий, подчеркивает интерес России выступать в конфликте при необходимости геополитическим арбитром: напрямую не участвующей стороной конфликта, однако стороной, которая определяет зависимость политики от обороноспособности стран Армении и Азербайджана.

На мировом геополитическом пространстве совершенно очевидной является позиция Турции, которая стремится доминировать в отношение географически близко расположенных стран. Управление конфликтом отчасти указывает на показательную силу, однако рамки её проявления ограничены присутствием других геополитических участников, в первую очередь, таких как Россия, а также Европейский союз и США.

Рассмотрим в качестве альтернативного взгляда на события в Нагорном Карабахе, обращаясь к интернет-изданию новостей ВВС.

\footnotetext{
527 The U.N. Must Investigate Nagorno-Karabakh War Crimes. [Электронный pecypc]: Foreign Policy. URL: https://foreignpolicy.com/2021/10/07/the-u-n-must-investigate-nagorno-karabakh-war-crimes/

${ }^{528} \mathrm{https}: / /$ www.vesti.ru/article/2523222
} 
Данный источник, возвращаясь к истории указывает, что политически Турция всегда была на стороне Азербайджана, а Армения, в свою очередь, акцентирует внимание на геноциде армянского народа в 1915г.: «Народы Турции и Азербайджана связывают тесные исторические и культурные связи, они говорят на языках из одной лингвистической семьи. Политически Турция всегда поддерживала Азербайджан особенно после развала СССР. При этом, интернет-издание так же обращает внимание на иранскую позицию, которая обеспокоена данным конфликтом, так как в Иране проживает много этнических армян и азербайджанцев: «Ирану также приходится балансировать между Баку и Ереваном. В Иране живет много этнических азербайджанцев - в основном на севере страны, у границ Азербайджана и Армении. Иранские власти обеспокоены возможностью возникновения сепаратистских настроений среди них. В Иране также достаточно многочисленная армянская диаспора» ${ }^{529}$.

Этот же источник оценивает данный конфликт и со стороны России, которая балансирует политическими и экономическими интересами как по отношению к Армении, так и к Азербайджану: «Россию связывает с Арменией и Азербайджаном многовековая история, но теперь все гораздо сложнее. И дело не только в том, что Россия - сопредседатель Минской группы ОБСЕ и как посредник должна слушать обе стороны. Россия продаёт оружие Армении и Азербайджану на многие миллиарды долларов. Российские компании владеют крупными экономическими активами в Армении. На территории Армении находится большая российская военная база. Большое число граждан Армении находится на заработках в России. Многие граждане Азербайджана тоже работают в России. Российский бизнес вложился в нефтяную индустрию Азербайджана. В самом Азербайджане - довольно много граждан с русскими корнями. Предполагается, что по этим причинам Россия не занимает однозначную позицию, поддерживая Баку или Ереван.

Интернет издание Washington Post отмечает, что в 2020г. региональные лидеры, такие как Россия и Турция, поделили сферы влияния, в то время как остальные страны оставались лишь наблюдателями: «Две внешние державы решительно повлияли на карабахскую войну 2020 года: Россия и Турция. Это говорит о том, что эпоха сделок между региональными лидерами возвращается, а Европа и Соединенные Штаты остаются в стороне. Введение российских миротворцев для обеспечения соблюдения

${ }^{529} \mathrm{https} / /$ www.bbc.com/russian/features-54427054 
новой карты усиливает влияние Кремля на Южный Кавказ. Но их миссия может оказаться трудной и вовлечь Россию в ожесточенный конфликт. Поддержка Турцией Азербайджана также позволила переделать Карабах и Южный Кавказ. Война может быть жестоким картографом. Авторитаристы снова проводят линии на картах - а все остальные приспосабливаются» ${ }^{530}$.

Так же WashingtonPost обращает внимание, что независимость Нагорного Карабаха не было признано ни одной страной ранее, что в итоге обусловило действия президента РФ поддержать сторону Азербайджана: «Независимость Нагорного Карабаха не была признана ни одним государством, в том числе и Арменией, и более двух десятилетий мирных переговоров в рамках Организации по безопасности и сотрудничеству в Европе не привели к соглашению о возвращении территории Азербайджану или о статусе анклава. По сделке, заключенной при посредничестве В.Путина, Азербайджан вернул семь районов и часть Нагорного Карабаха, включая стратегический город Шуша» ${ }^{531}$.

Интернет-издание EurAsia Daily в статье от 17.10.2020г отмечает взаимосвязь конфликта Нагорного Карабаха и Шелкового пути, который связан с интересами Китая в части транспортного коридора, пишет автор статьи Николай Вавилов: «Китай внимательно наблюдает за событиями в Закавказье. Через этот регион пролегает один из коридоров для беспрепятственного движения китайских товаров в Европу по континентальному безопасному от американского флота маршруту. По словам эксперта, из-за ситуации в Нагорном Карабахе инфраструктурные проекты Китая в области железнодорожного и автомобильного сообщения не могут быть реализованы, «их эффективность ставится под сомнение». «Проблема Карабаха глобально влияет на проблему «Шелкового пути», - считает китаист, отмечая при этом, что каждая из веток «Шелкового пути» находится в «очень крупной геополитической зависимости от нарастающего китайско-американского противодействия» ${ }^{532}$.

Особая значимость Азербайджана как транспортной артерии в контексте глобальных экономических интересов отмечается так же в интернет-издании Octagon: «Кавказский и Каспийский регионы - точка пересечения двух транспортных

\footnotetext{
530 https://www.washingtonpost.com/politics/2020/11/16/five-ways-2020-nagorno-karabakh-conflict-willchange-map/

531 https://www.washingtonpost.com/world/europe/armenia-nagorno-karabakh-frontline/2020/11/22/c0bdc1e62b52-11eb-9c21-3cc501d0981f_story.html

532 https://eadaily.com/ru/news/2020/10/17/voyna-v-karabahe-vliyaet-na-proekt-shelkovyy-put-kitay-otvetitcherez-iran
} 
коридоров. Первый - это китайский проект «Восток - Запад», или «Великий шёлковый путь», частью которого являются перевалочные хабы в Грузии и Азербайджане. Второй маршрут «Север - Юг» связывает индийский Мумбаи с российским СанктПетербургом. В нём партнёр Индии и России - Иран, который вложил много финансовых средств и организационных усилий в строительство на территории Азербайджана железнодорожных переходов, соединяющих иранскую и российскую железнодорожные сети. Эти регионы - объекты пристального интереса со стороны Турции, президент которой Реджеп Эрдоган одержим идеей реанимации Османской империи. США и Великобритания рассматривают Кавказ как плацдарм для атаки или давления на Россию и Иран. С другой стороны, контролирующие маршруты морской торговли англосаксы не заинтересованы в конкурентах в виде сухопутных коридоров и потому были бы не прочь устроить на Кавказе несовместимый с нормальной работой хаос и под шумок захватить командные высоты для локализации в регионе своих военных баз. Решение задачи переформатирования и хаотизации Кавказа можно возложить на Турцию, которая прекрасно справится с ней, особенно если курировать этот проект будут её старые британские партнёры» ${ }^{533}$.

В контексте вышеизложенного можно предположить, что ситуации в Нагорном Карабахе отводится осевая роль противостояния полярных геополитических игроков в лице США, Великобритании с одной стороны и России с Китаем, с другой стороны. В данном формате Турция занимает позицию буферной зоны, если исходить из паритета военного и экономического веса остальных заинтересованных сторон в разрешении данного конфликта.

Исход конфликта в Нагорном Карабахе послужил условием укрепления уровня лояльности между Азербайджаном и Турцией, однако бросил тень на их способность удерживать необходимый уровень геополитической толерантности в рамках стремления стран участниц конфликта к развитию и расширению экономического и политического сотрудничества с Европейскими странами. Несмотря на то, что Турция является членом НАТО, а также ассоциированным членом Европейского союза, действия скорее указывают на независимую линию геополитического вектора Анкары.

Различные предположения выносились на рассмотрение со стороны Европейского Союза, в части необходимости решения данной проблемы, как одной из важных, среди соседствующих стран - Азербайджана, Армении и Грузии: «В середине

533 octagon.media/politika/nagornyj_karabax_boj_mestnogo_znacheniya_v_vojne_za_peredel_mira.html 
2003г. Совет министров ЕС назначил в регион своего специального представителя, главной задачей которого ставилось содействие установлению мира в трех странах южно-кавказского региона: Азербайджана, Армении и Грузии - возвращению беженцев в эти страны и урегулированию конфликтов в регионе и, в частности, Нагорно-Карабахского. Но на практике, деятельности этого спецпредставителя свелась к помощи миссиям ООН и ОБСЕ в регионе, а в 2006 г. его роль была расширена до участия в переговорном процессе между сторонами конфликта, контроль процесса перемещения беженцев, контроль за соблюдением границ и контролю за ситуацией с наркотрафиком, торговлей оружием и психотропными веществами». ${ }^{534}$

Важно так же упомянуть совместные инициативы в рамках Минской группы ОБСЕ, которые были разработаны в 2009г. для мирного урегулирования НагорноКарабахского конфликта и включали следование нижеследующим принципам: ${ }^{535}$

- возвращение территорий вокруг Нагорного Карабаха под контроль Азербайджана;

- предоставление промежуточного статуса для Нагорного Карабаха, обеспечивающего гарантии безопасности и самоуправления;

- обеспечение коридора, связывающего Армению с Нагорным Карабахом;

- определение будущего окончательного правового статуса Нагорного Карабаха путем имеющего обязательную юридическую силу волеизъявления;

- возвращение всех внутренне перемещенных лиц и беженцев в места прежнего проживания;

- международные гарантии безопасности и проведение миротворческой операции».

Необходимо так же отметить, что Франция в настоящее время так же не признает независимость Нагорного Карабаха. Можно предположить, что непризнание может быть обусловлено экономическим сотрудничеством с Азербайджаном, которое наметилось еще со времён распада СССР. Так, в речи Президента Азербайджана Гейдара Алиева 13.01.1997 было заявлено следующее: «Я совершенно согласен с тем, что наше сотрудничество с "Эльф Акитен" и другими компаниями Франции

\footnotetext{
${ }^{534} \mathrm{https}: / /$ politcom.org.ua/na-kavkaz-cherez-bryussel 535

https://caucasusedition.net/ru/\%D0\%BC\%D0\%B0\%D0\%B4\%D1\%80\%D0\%B8\%D0\%B4\%D1\%81\%D0\%BA\% D0\%B8\%D0\%B5-\%D0\%BF\%D1\%80\%D0\%B8\%D0\%BD\%D1\%86\%D0\%B8\%D0\%BF\%D1\%8B$\% \mathrm{D} 0 \% \mathrm{BE} \% \mathrm{D} 1 \% 81 \% \mathrm{D} 0 \% \mathrm{BD} \% \mathrm{D} 0 \% \mathrm{BE} \% \mathrm{D} 0 \% \mathrm{~B} 2 \% \mathrm{D} 0 \% \mathrm{~B} 0-\% \mathrm{D} 0 \% \mathrm{~B} 4 \% \mathrm{D} 0 \% \mathrm{BB} \% \mathrm{D} 1 \% 8 \mathrm{~F}-$ $\% \mathrm{D} 1 \% 83 \% \mathrm{D} 1 \% 80 \% \mathrm{D} 0 \% \mathrm{~B} 5 \% \mathrm{D} 0 \% \mathrm{~B} 3 \% \mathrm{D} 1 \% 83 /$
} 
стремительно развивается... Хочу выразить уверенность в том, что подписание сегодня при участи президентов Франции и Азербайджана во Франции, в резиденции Президента в Елисейском дворце, контрактов о совместном использовании месторождений "Лянкяран-дениз" и "Талыш-дениз" станет историческим событием в основательном развитии экономических связей между нашими странами» ${ }^{536}$.

Таким образом, экономическое сотрудничество двух стран в нефтяной сфере, определяет особую степень лояльности Франции к Азербайджану в контексте поддержки территориальных интересов последнего. Однако, Франция, являясь членом Европейского союза, так же выступает в роли партнера по отношению к Армении, в рамках программы Восточного партнерства начиная с 2009г. Из этого можно предположить, что благодаря Восточному партнерству, может появиться решение в части определения совместных усилий в нахождении мирного и окончательного решения вопроса между Арменией и Азербайджаном.

Уже в мае 2018г. Президент Франции Эммануэль Макрон в своём письме заверил Президента Азербайджана Ильхама Алиева в поддержке сближения с ЕС и помощи в урегулировании конфликта: «Азербайджан всегда может полагаться на поддержку Франции в решении будущих задач и в вопросе продолжения сближения с Европейским союзом. Позвольте еще раз отметить, что Франция как сопредседатель Минской группы не пожалеет усилий для справедливого и продолжительного урегулирования Нагорно-Карабахского конфликта путем переговоров» ${ }^{537}$.

Рассмотрим сложившуюся ситуацию в Нагорном Карабахе, после завершения военных действий: «Боевые действия в Нагорном Карабахе завершились 10 ноября 2020 года после подписания трехстороннего соглашения о прекращении боевых действий в Нагорном Карабахе днем ранее. Документ в том числе предусматривает введение в регион российских миротворцев, обмен пленными между сторонами конфликта, передачу Арменией Азербайджану ряда районов региона и возвращение беженцев в Карабах ${ }^{538}$.

Армянское население, многие люди, проживавшие в Нагорном Карабахе, крайне радикально отреагировали на договоренности о прекращении военных действий и договоренностей в пользу Азербайджана: «Уже несколько дней армяне массово покидают территории Нагорного Карабаха, которые по договору между Арменией,

\footnotetext{
${ }^{536} \mathrm{https}$ ://lib.aliyevheritage.org/ru/9375267.html

${ }^{537} \mathrm{http}: / / \mathrm{cbc} . \mathrm{az} / \mathrm{ru} / \mathrm{news} / \mathrm{news} 1527347061$

${ }^{538} \mathrm{https} / /$ iz.ru/1126161/2021-02-17/putin-obsudil-s-pashinianom-realizatciiu-dogovorennostei-po-karabakhu
} 
Россией и Азербайджаном вскоре должны перейти последнему. Свои дома они сжигают, чтобы те не достались азербайджанцам, а кровлю, ценные вещи, электроприборы и домашних животных пытаются вывезти. По дороге в Армению гонят коров и овец, а грузовики транспортируют лес: его тоже пилят в Карабахе. 25 ноября 2020г. Кельбаджарский район тоже официально отойдет Азербайджану» ${ }^{539}$.

Между тем, статус русского языка на территории Нагорного Карабаха обсуждается на уровне первых лиц государства и признается официальным: «Президент непризнанной Нагорно-Карабахской Республики (Арцаха) Араик Арутюнян подписал закон о признании русского языка официальным. Об этом 17 февраля сообщается на сайте Национального собрания республик. Отмечается, что согласно проекту изменений, в законе «О языке» официальными языками НКР признаются литературный армянский и русский». ${ }^{540}$

Достигнутая договоренность о переходе Нагорного Карабаха к Азербайджану не встретила необходимую поддержку со стороны населения Армении, многие люди решили открыто об этом заявить: «После недолгой передышки политическая ситуация в Армении вновь накалилась. 25 февраля 2021 г. генштаб республики выступил с призывом к главе правительства уйти в отставку. Минобороны коллег не поддержало, заявив, что армия не должна вмешиваться в политику. Однако позиция генштаба нашла понимание у большинства оппозиционных политиков и немалой части народа. Как заявили «Известиям» в «Процветающей Армении», уход лидера страны уже стал «национальным требованием». Сам премьер-министр Никол Пашинян назвал заявление генштаба попыткой военного переворота, объявил об увольнении его главы Оника Гаспаряна и призвал своих сторонников выйти на улицы. Впрочем, туда же вышли и его противники» ${ }^{541}$.

Вместе с тем, оппозиционное движение в Армении выступает в поддержку развития диалога о получении статуса союзника США вне НАТО, тем самым создавая линию напряжения в рамках договорённостей о присутствии российских военных миротворцев в этом регионе: «Армении необходимо диверсифицировать источники приобретения оружия, а также получить статус союзника США вне НАТО, заявили

\footnotetext{
539 https://hromadske.ua/ru/posts/karabah-posle-mira-armyane-zhgut-svoi-doma-chtoby-oni-ne-dostalisazerbajdzhancam

${ }^{540}$ https://iz.ru/1125892/2021-02-17/russkii-iazyk-byl-priznan-ofitcialnym-v-nagornom-karabakhe

$541 \quad$ https://iz.ru/1129471/nataliia-portiakova-aleksei-zabrodin/nikola-so-dvora-k-chemu-privedet-novoeobostrenie-v-armenii
} 
участники акции, организованной "Национально-демократическим полюсом" в Ереване..."Это новая национально-освободительная борьба", - заявил на акции один из лидеров движения Жирайр Сефилян ${ }^{542}$.

\section{Выводы}

По сей день многовековой конфликт двух народов до сих пор остается не разрешенным.

Из всего вышеизложенного следует, что исторически на протяжении многих веков конфликт в Нагорном Карабахе разжигался, и заинтересованными сторонами оказывались не только Армения или Азербайджан, но также Турция, Советская Россия и СССР, а также Великобритания и ЕС отстаивают свою точку зрения по поводу данного конфликта. Учитывая относительно небольшую географическую площадь около 4400 кв.км., эта территория имеет весомое значение на геополитическом пространстве, в том числе как важный транспортный коридор. В современном, индустриально-инновационном мире, где определяющая роль политики основывается на итоговом финансовом результате всех процессов для вовлеченных сторон, несложно предположить очевидный интерес к конфликту со стороны крупнейших стран геополитических игроков. Вопрос мирного урегулирования данного вопроса попрежнему остается открытым.

Очевидно, что непринятие населением Армении сложившейся ситуации может привести к внутренним противостояниям, что чревато конфликтами внутри страны. Будет ли достаточно у властей необходимых возможностей для сохранения мира и статуса-кво после подписания трёхсторонних договоренностей в ноябре 2020г. покажет время.

Для Азербайджана, как и для Армении, социально-экономическое развитие имеет особое значение, прежде всего в части развития международных отношений, совершенствования политических институтов и дальнейшую имплементацию интеграционных инициатив, закрепленных политическими соглашениями о Восточном партнерстве, а также соглашения о партнерстве и сотрудничестве с Европейским Союзом. Успех реализации теперь зависит как от политических элит, так и от гражданского населения обоих государств.

\footnotetext{
542 https://www.kavkaz-uzel.eu/articles/361467/
} 


\section{Streszczenie:}

Publikacja opisuje historyczny przebieg wydarzeń od samego początku wybuchu konfliktu w Górskim Karabachu, którego początki sięgają końca XIX wieku. Konflikt od ponad 100 lat kojarzony jest $\mathrm{z}$ różnymi wydarzeniami. W ciągu ostatnich 25 lat konflikt w Górskim Karabachu ponownie stał się niezwykle aktualny w przestrzeni geopolitycznej. W artykule zostały przeanalizowane punkty widzenia mediów Armenii, Azerbejdżanu, Rosji, Turcji, USA, Unii Europejskiej. Obecnie różne środki informacji publicznej z każdej strony, w różnych krajach, na różne sposoby opisują tę sytuację konfliktową. Niniejsza publikacja analizuje opis konfliktu z różnych stron, na podstawie opinii różnych mediów, co pozwoli głębiej i lepiej zorientować się w tej sytuacji.

\section{Slowa kluczowe:}

Górski Karabach, konflikt, przestrzeń geopolityczna, Armenia, Azerbejdżan

\section{Key words:}

Nagorno-Karabakh, conflict, geopolitical space, Armenia, Azerbaijan

\section{Bibliografia:}

1. Нагорно-Карабахская проблема. [Электронный ресурс]: Министерство Иностранных Дел Республики Армения. URL: https:/www.mfa.am/ru/nagornokarabakh-issue

2. История Нагорного Карабаха. [Электронный ресурс]: Национальная Академия Наук Азербайджана. Институт Молекулярной Биологии и Биотехнологий. URL: https://imbb.az/az/news/841

3. Карабах с древнейших времен до времен ханств. [Электронный ресурс]: Виртуальный Карабах. Центр информационно-коммуникационных технологий. URL: $\quad$ https:/www.virtualkarabakh.az/az/post-item/22/32/qarabag-en-qedimzamanlardan-xanliqlar-dovrunedek.html

4. Организация Объединенных Наций. Международные Договоры по Правам Человека. Основной документ, являющийся составной частью докладов государств-участников. Азербайджанская Республика [31 января 2002 года]. [Электронный ресурс] URL: http://docstore.ohchr.org/SelfServices/FilesHandler.ashx?enc=FhOD6sgqgzAhFXD9F \%2FeKaFMm83LbFY75RhkIFGrig\%2B4vCnJiMzyLfHoDODRgFZF3aJ3o6haDraXw hCUv4X9ErNAKk1jrzXC0JwCMI76aA8tjpCjgKTwcOZaTjfCAhJDarYCBalKNgtnsv 4rBkqeixA\%3D\%3D 
5. Нагорный Карабах: история земли, за которую снова разгорается война. [Электронный ресурс]: Информационное агентство «В городе N». URL: https://www.vgoroden.ru/statyi/nagornyy-karabah-istoriya-zemli-za-kotoruyu-snovarazgoraetsya-voyna

6. Что случилось в Нагорном Карабахе? Отвечаем на главные вопросы. [Электронный ресурc]: BBC News. Русская служба. URL: https://www.bbc.com/russian/features-54427054

7. 44 gün sürən Vətən Müharibəsi (II Qarabağ müharibəsi). [Электронный ресурс]: сайта Генеральной Прокуратуры Азербайджанской Республики. URL: https://genprosecutor.gov.az/az/page/azerbaycan/i-ve-ii-qarabag-muharibesi/44-gunsuren-veten-muharibesi-ii-qarabag-muharibesi

8. Путин не стал воевать в Карабахе - Гордон назвал две причины. [Электронный pecypc]: Телеканал Украина 24. URL: https:/old.u24.ua/vmire-news/5734-putin-nestal-voevat-v-karabahe-gordon-nazval-dve-prichiny

9. Совещание о российской миротворческой миссии в Нагорном Карабахе[Электронный ресурс]: Официальный сайт Президента России. URL: http://kremlin.ru/events/president/news/64455

10. Мурад Мурадов: Россия и Вторая Карабахская Война. [Электронный ресурс]: Центр Досліджень Армії, Конверсії Та Роззброєння. URL: https://cacds.org.ua/мурад-мурадов-россия-и-вторая-карабах/

11. Qarabağda sülhlə bağlı 7 sual. Bundan qazanan kimdir və sonra nə olacaq? [Электронный ресурc]: BBC News. Azerbaycanca. URL: https://www.bbc.com/azeri/region-54878142

12. Трамп: "Армяне дерутся как черти". [Электронный ресурс]: BBC News. URL: https://www.bbc.com/russian/live/news-54317944

13. Лукашенко поздравил Армению и Азербайджан с окончанием конфликта в Карабахе. [Электронный ресурс]: ИА Красная Весна. URL: https://rossaprimavera.ru/news/f7197bf7

14. Политолог Алексей Малашенко - об иранском факторе в Нагорном Карабахе. [Электронный ресурс]: Журнал "Огонёк" №41 от 19.10.2020, стр. 16 URL: https://www.kommersant.ru/doc/4529330

15. Коментар: Кому вигідна війна за Нагірний Карабах [Электронный ресурс]: Deutsche Welle. URL: https://p.dw.com/p/3jAnG

16. Эксперты о ситуации в Карабахе: мир с далеко идущими последствиями [Электронный ресурc]: Deutsche Welle. URL:https://p.dw.com/p/3lcS7

17. Second Keynote Speech by German Federal Minister of Defence [Электронный pecypc]: Federal Ministry of Defence. URL:https://www.bmvg.de/en/news/secondkeynote-speech-german-minister-of-defence-akk-4503976

18. Chan, Eric, "What Taiwan's Military Can Learn From the Armenia-Azerbaijan War". December 09, 2020. [Электронный pecypc]: The Diplomat. URL: https://thediplomat.com/2020/12/what-taiwans-military-can-learn-from-the-armeniaazerbaijan-war/ 
19.

European

Parliament

URL:

https://www.europarl.europa.eu/cmsdata/238542/20210730_AZ-

AM\%20border\%20clashes_joint\%20statement.pdf

20. France's Macron Calls For Azerbaijani Troop Pullout From 'Armenian Territory' [Электронный ресурс]: Radio Free Europe/Radio Liberty. URL: https://www.rferl.org/a/france-macron-nagorno-karabakh/31284862.html

21. The U.N. Must Investigate Nagorno-Karabakh War Crimes. [Электронный ресурс]: Foreign Policy. URL: https://foreignpolicy.com/2021/10/07/the-u-n-must-investigatenagorno-karabakh-war-crimes/

22. https://www.vesti.ru/article/2523222

23. https://www.bbc.com/russian/features-54427054

24. https://www.politico.eu/article/turkey-erdogan-year-of-belligerence

25. https://www.washingtonpost.com/politics/2020/11/16/five-ways-2020-nagornokarabakh-conflict-will-change-map/

26. https://www.washingtonpost.com/world/europe/armenia-nagorno-karabakhfrontline/2020/11/22/c0bdc1e6-2b52-11eb-9c21-3cc501d0981f_story.html

27. https://eadaily.com/ru/news/2020/10/17/voyna-v-karabahe-vliyaet-na-proektshelkovyy-put-kitay-otvetit-cherez-iran

28 .

octagon.media/politika/nagornyj_karabax_boj_mestnogo_znacheniya_v_vojne_za_pere del mira.html

29. https://www.kavkaz-uzel.eu/articles/49312/

30. https://politcom.org.ua/na-kavkaz-cherez-bryussel

31.https://caucasusedition.net/ru/\%D0\%BC\%D0\%B0\%D0\%B4\%D1\%80\%D0\%B8\%D0\% B4\%D1\%81\%D0\%BA\%D0\%B8\%D0\%B5-

$\% \mathrm{D} 0 \% \mathrm{BF} \% \mathrm{D} 1 \% 80 \% \mathrm{D} 0 \% \mathrm{~B} 8 \% \mathrm{D} 0 \% \mathrm{BD} \% \mathrm{D} 1 \% 86 \% \mathrm{D} 0 \% \mathrm{~B} 8 \% \mathrm{D} 0 \% \mathrm{BF} \% \mathrm{D} 1 \% 8 \mathrm{~B}-$

$\% \mathrm{D} 0 \% \mathrm{BE} \% \mathrm{D} 1 \% 81 \% \mathrm{D} 0 \% \mathrm{BD} \% \mathrm{D} 0 \% \mathrm{BE} \% \mathrm{D} 0 \% \mathrm{~B} 2 \% \mathrm{D} 0 \% \mathrm{~B} 0-$

$\% \mathrm{D} 0 \% \mathrm{~B} 4 \% \mathrm{D} 0 \% \mathrm{BB} \% \mathrm{D} 1 \% 8 \mathrm{~F}-\% \mathrm{D} 1 \% 83 \% \mathrm{D} 1 \% 80 \% \mathrm{D} 0 \% \mathrm{~B} 5 \% \mathrm{D} 0 \% \mathrm{~B} 3 \% \mathrm{D} 1 \% 83 /$

32. https://lib.aliyevheritage.org/ru/9375267.html

33. http://cbc.az/ru/news/news1527347061

34. https://iz.ru/1126161/2021-02-17/putin-obsudil-s-pashinianom-realizatciiudogovorennostei-po-karabakhu

35. https://hromadske.ua/ru/posts/karabah-posle-mira-armyane-zhgut-svoi-doma-chtobyoni-ne-dostalis-azerbajdzhancam

36. https://iz.ru/1125892/2021-02-17/russkii-iazyk-byl-priznan-ofitcialnym-v-nagornomkarabakhe

37. https://iz.ru/1129471/nataliia-portiakova-aleksei-zabrodin/nikola-so-dvora-k-chemuprivedet-novoe-obostrenie-v-armenii

38. https://www.kavkaz-uzel.eu/articles/361467/ 